DOI: 10.34015/2523-4552.2019.4.14

УдК 343.2

Боровик А. В.,

кандидат юридичних наук, доцент, професор кафедри кримінального права $i$ правосуддя Міжнародного економікогуманітарного університету імені академіка Степана Дем'янчука e-mail:aborovychok@gmail.com ORCID: 0000-0003-1834-404X

\title{
ПИТАННЯ КРИМІНАЛЬНОЇ ВІДПОВІДАЛЬНОСТІ ТА ЗАПОБІГАННЯ КОРУПЦІЙНИМ КРИМІНАЛЬНИМ ПРАВОПОРУШЕННЯМ У ПОЛОЖЕННЯХ ОКРЕМИХ МІЖНАРОДНИХ ДОКУМЕНТІВ
}

У статті розглянуто питання кримінальної відповідальності та запобігання корупційним кримінальним правопорушенням у положеннях окремих міжнародних документів - конвенцій, резолюцій, декларацій, модельних кодексів тощо. Встановлено, що основні міжнародні документи, які регулюють питання міжнародного співробітництва різних держав світу в сфері кримінальної відповідальності та запобігання корупційним кримінальним правопорушенням, були ухвалені у період з 1975 по 2010 рр., однак лише окремі з них ратифіковані Україною.

Ключові слова: корупційні кримінальні правопорушення; корупція; хабарництво; конвенція; резолюція; декларація; модельний кодекс.

В статье рассмотрены вопросы уголовной ответственности и предотвращения коррупционных уголовных правонарушений в положениях отдельных международных документов - конвенций, резолюций, деклараций, модельных кодексов. Установлено, что основные международные документы, регулирующие вопросы международного сотрудничества разных стран в сфере уголовной ответственности и предотвращения коррупционных уголовных правонарушений, были приняты в период с 1975 по 2010 гг., однако лишь некоторые из них ратифицированы Украиной.

Ключевые слова: коррупционные уголовные правонарушения; коррупция; взяточничество; конвенция; резолющия; декларация; модельный кодекс.

Постановка проблеми. Загальновідомо, що початком розвитку міжнародно-правового регулювання у сфері боротьби з корупцією та іï різноманітними проявами (зокрема, корупційними кримінальними правопорушеннями (далі-ККП)) було прийняття 15 грудня 1975 р. Резолюції Генеральної Асамблеї $\mathrm{OOH}$ № 3514(XXX) «Заходи проти корупції, що практикується транснаціональними та іншими корпораціями, їх посередниками та іншими причетними до цього сторонами» [1], в якій 
засуджувалися всі види корупції (у т.ч. й хабарництво) та розроблялися рекомендації щодо запровадження державами заходів, необхідних для запобігання й протидії корупції. Окреслені завдання не тільки були деталізовані у Резолюції Генеральної Асамблеї ООН «Боротьба 3 корупцією» (№ A/RES/51/59) (1996р.), Декларації ООН «Про боротьбу з корупцією та хабарництвом у міжнародних комерційних операціях» (1996 р.), Міжнародному кодексі поведінки державних посадових осіб (1996 р.), Керуючих принципах для ефективного виконання Кодексу поведінки посадових осіб 3 підтримання правопорядку (1989 р.), а й заклали підвалини для створення міжнародних нормативно-правових актів, що закріпили універсальні стандарти запобігання корупційним проявам [2, с. 9].

Звернення до сучасної юридичної літератури та текстів відповідних міжнародних правових актів дає нам змогу констатувати, що на даний час основними документами, які регулюють питання міжнародного співробітництва різних держав світу в сфері кримінальної відповідальності та запобігання ККП, $є$ відповідні конвенції, додаткові протоколи до них, резолюції, рекомендації, угоди, статути, договори та ін. Подальша наукова розробка цих міжнародних документів сприятиме уточненню й конкретизації низки нормативних вимог, допоможе виявити у них позитивні та негативні характеристики, визначити межі та ступінь регулювання кримінально-правових і кримінологічних положень тощо.

Аналіз останніх досліджень і публікацій. Наукові дослідження змісту та сутності міжнародноправових інструментів у сфері кримінальної відповідальності та запобігання ККП здійснювала ціла низка вчених-правників, наприклад, Д. Гарбазей, Л. Гаухман, Г. Жаровська, Н. Задирака, Б. Костенко, Р. Кабанець, А. Кухарчук, О. Макухін, I. Ніженська, I. Нуруллаєв, С. Петрашко, А. Політова, Р. Половинкіна, А. Савченко, О. Соснін, Х. Федорчак, А. Швецов та ін., однак результати їх розробок різнилися між собою за своїм обсягом, підходами та форматом. В одних випадках науковці розробляли положення виключно щодо корупції та не торкалися решти її проявів, в інших - акцентували увагу або на кримінально-правових, або на кримінологічних характеристиках корупційних діянь, тоді як третя група дослідників зосереджувалася тільки на питаннях міжнародного співробітництва держав і т. ін. За вказаних умов невирішеним моментом залишаються питання деталізації відповідних положень про кримінальну відповідальність і запобігання ККП з урахуванням юридичних, міжгалузевих та семантичних особливостей.

Постановка завдання. Метою цієї наукової статті є розгляд питань про кримінальну відповідальність і запобігання ККП у положеннях окремих міжнародних документів, тобто тих, що становлять дослідницький інтерес з огляду на їх принципову важливість або недостатню розробленість, а також формулювання на цій основі відповідних висновків.

Виклад основного матеріалу. У сучасному світі за декілька останніх десятиліть ухвалено значну кількість міжнародно-правових (універсальних, регіональних та субрегіо- 
нальних) документів щодо кримінальної відповідальності та запобігання ККП. Залежно від дати ухвалення, за зростанням, це такі міжнародні документи: Резолюція 34/169 Генеральної Асамблеї ООН «Кодекс поведінки посадових осіб 3 підтримання правопорядку» від 17 грудня 1979 р.; Дев'ятнадцята (Мальта, 1994 р.), Двадцять Перша (Чеська Республіка, 1997 р.) i Двадцять Друга (Молдова, 1999 р.) конференції міністрів юстиції європейських країн; Міжамериканська конвенція проти корупції, прийнята Організацією американських держав 29 березня 1996 р.; Міжнародний кодекс поведінки державних посадових осіб від 23 липня 1996 р.; Декларація ООН про боротьбу з корупцією i хабарництвом у міжнародних комерційних операціях від 16 грудня 1996 р.; Резолюція Генеральної Асамблеї ООН «Боротьба з корупцією» від 12 грудня 1996 р.; Конвенція про боротьбу з корупцією, яка зачіпає посадових осіб Європейських Співтовариств або посадових осіб держав - членів ЄС, прийнята Радою ЄС 26 травня 1997 р.; Резолюція (97) 24 Комітету міністрів РЄ «Про двадцять принципів боротьби 3 корупцією» від 06 листопада 1997 р.; Конвенція про боротьбу з підкупом іноземних посадових осіб у міжнародних комерційних угодах, прийнята Організацією економічного співробітництва та розвитку 21 листопада 1997 р.; Угода про створення групи держав по боротьбі 3 корупцією (GRECO) від 05 травня 1998 р.; Статут Групи держав по боротьбі з корупцією (GRECO) від 05 травня 1998 р.; Кримінальна конвенція РЄ про боротьбу з корупцією (ETS 173) від 27 січня 1999 р.; Цивільна конвенція РЄ про боротьбу з корупцією (ЕTS 174) від 04 листопада 1999 р.; Рекомендація № R (2000) 10 Комітету Міністрів державам-членам PЄ щодо кодексів поведінки державних службовців 11 травня 2000 р.; Конвенція ООН проти транснаціональної організованої злочинності від 15 листопада 2000 р.; Рекомендація Rec 2003(4) Комітету Міністрів PE «Про загальні правила боротьби з корупцією при фінансуванні політичних партій та виборчих кампаній» від 08 квітня 2003 р.; Додатковий протокол до Кримінальної конвенції про боротьбу з корупцією (ETS 191) від 15 травня 2003 р.; Комюніке Європейської комісії щодо комплексної політики Європейського Союзу з протидії корупції від 28 травня 2003 р.; Конвенція Африканського союзу про недопущення корупції та боротьбу з нею від 12 липня 2003 р.; Рамкове рішення Ради ЄС № 568 від 22 липня 2003 р. «Про боротьбу 3 корупцією в приватному секторі»; Конвенція ООН проти корупції від 31 жовтня 2003 р.; Конвенція Ліги арабських держав про боротьбу з корупцією від 21 грудня 2010 р. та деякі інші.

Наголосимо, що більшість із наведених вище міжнародних документів було ретельно розглянуто у своїх дослідженнях вченимиправниками, тому немає необхідності проводити аналогічні наукові пошуки. Однак, беручи до уваги важливість, принциповість, практичну значущість або недослідженість окремих міжнародних документів антикорупційного спрямування (при цьому, на наш погляд, європейські правові акти подібного типу, зважаючи на їх регіональну наближеність до України та особливу 
євроінтеграційну роль, потребують розробки в межах окремого дослідження) для кримінального права та кримінології в порівняльноправовому контексті, пропонуємо далі докладно та послідовно здійснити їх розгляд у межах цієї статті. Крім того, слід ураховувати той факт, що Українська держава $€$ учасницею низки міжнародноправових договорів і конвенцій, які мають обов'язковий характер, та актів рекомендаційного спрямування (рекомендацій, резолюцій, інструкцій) і прийняті в ООН, ОЕСР, ОАД, Р€, ЄС, АС [3, с. 16]. Відтак, це є додатковим аргументом для поглибленого дослідження відповідних міжнародних стандартів щодо кримінальної відповідальності та запобігання ККП, що буде важливим для подальшого вдосконалення державної антикорупційної політики в Україні.

За нашим переконанням, на початку варто проаналізувати положення Міжамериканської конвенції про боротьбу з корупцією, що була прийнята на третій пленарній сесії держсав-членів організації американських держав 29 березня 1996 р. у Каракасі (Венесуела) та набула чинності 06 березня 1997 р. (при цьому, згідно зі ст. 23 «Приєднання», ця Конвенція залишається відкритою для приєднання будь-якої іншої держави, але на даний час, крім держав-учасниць ОАД, жодна країна світу поки не приєдналася до вказаного договору). Конвенція складається 3 преамбули та 25 статей і за суттю $є$ першим антикорупційним міжнародно-правовим документом не тільки в американському регіоні, а й у світі. У ній різнопланово реалізовані кри- мінально-правові, кримінальні процесуальні, кримінологічні та інші питання. На даний час її ратифікувало 34 країни.

Положення цієї Конвенції щодо кримінальної відповідальності за ККП викладені у: а) ст. 1 «Визначення», де розтлумачується значення таких термінів: «публічна функція»; «публічна посадова особа», «урядовий чиновник», або «державний службовець»; «власність»; б) ст. 6 «Акти корупції», де передбачено, що вони охоплюють п'ять основних форм; ст. 8 «Транснаціональне хабарництво»; ст. 9 «Незаконне збагачування» (крім того, зважаючи на ст. 11 «Прогресивний розвиток», актами корупції повинні бути визнані й деякі інші протиправні діяння, у т.ч. й у формі «бездіяльності», а відповідно до ст. 12 цієї Конвенції, не обов'язково, щоб акти корупції завдавали шкоди державній власності); в) ст. 13 «Екстрадиція» та ст. 17 «сутність акту», де вказано, що, маючи на увазі цілі ст. 13, 14, 15 і 16 цієї Конвенції, той факт, що власність, придбана або здобута у результаті скоєння акту корупції, призначалася для політичних цілей, або те, що припускається, що акт корупції був скоєний $з$ політичних мотивів або цілей, не мусять бути достатніми i самі по собі не повинні кваліфікувати акт як політичний злочин або як звичайний злочин, пов'язаний 3 політичним злочином.

Щодо положень про запобігання ККП, то у цій Конвенції вони відбиті насамперед у: ст. 3 «Превентивні заходи», які включають 12 позицій - від визначення норм поведінки для правильного, чесного і належного виконання публічних функцій до проведення досліджень 3 
подальших превентивних заходів, що беруть до уваги взаємозв'язок між справедливою винагородою i непідкупністю на публічній службі; ст. 14 «Допомога і співробітництво»; ст. 15 «Заходи щодо власності»; ст. 18 «Центральні органи». Інші статті цієї Конвенції можуть містити положення кримінального процесуального та іншого характеру [4].

У Декларації ООН про боротьбу з корупцією і хабарництвом $у$ міжнародних комерційних операціях від 16 грудня 1996 р. йдеться про: вжиття ефективних і конкретних заходів боротьби з усіма формами корупції, хабарництва і пов'язаними 3 ними протиправними діями у міжнародних комерційних операціях; встановлення на ефективній і погоджувальній основі кримінальної відповідальності за дачу хабарів іноземним державним посадовим особам. Кримінально-правові заходи щодо протидії ККП у ній відбиті досить вузько та стосуються положень про: елементи, які мають включати хабарництво (п. 3); можливість визнання незаконного збагачення державних посадових осіб або обраних представників злочином (п. 7).

Кримінологічні заходи запобігання ККП утілені більш широко, зокрема у положеннях про: а) недопущення у країнах можливості відрахування з обкладених податком сум хабарів, виплачених будь-якою приватною або державною корпорацією чи окремою особою будь-якої держави-члена будь-якій державній посадовій особі або обраному представнику іншої країни, і з цією метою розгляд відповідних можливостей для досягнення цієї мети (п. 4); б) необхідність: розроблення чи застосовування стандартів і методів обліку, які підвищують транспарентність міжнародних комерційних операцій і спонукають приватні корпорації (п. 5), або розроблення чи заохочення розробки кодексів поведінки у галузі підприємницької діяльності, стандартів і оптимальної практики, які забороняють корупцію, хабарництво і пов'язані з ними протиправні дії при здійсненні міжнародних комерційних операцій (п. 6); в) взаємну допомогу щодо кримінальних розслідувань та інших судових розглядів, порушених $\mathrm{y}$ зв'язку з корупцією та хабарництвом у міжнародних комерційних операціях (п. 8); г) вжиття необхідних дій щодо зміцнення співробітництва 3 метою сприяння полегшенню доступу до документів та відомостей про операції і особистості тих, хто займається хабарництвом при здійсненні міжнародних комерційних операцій (п. 9); г) забезпечення того, щоб положення про нерозголошення банківської таємниці не перешкоджали кримінальним розслідуванням або іншим судовим розглядом щодо корупції, хабарництва й пов'язаної з цим незаконної практики у рамках міжнародних комерційних операцій і щоб всебічне співробітництво надавалося урядам, які намагаються отримати інформацію про такі операції (п. 10) [5].

Важливим для антикорупційної тематики $є$ й модельне законодавство. У цьому зв'язку варто проаналізувати положення Модельного закону про боротьбу з корупцією, який було прийнято на 13 пленарному засіданні Міжпарламентської Асамблеї держсав - учаснищь СНД (постанова № 13-4 від 03 квітня 1999 р.), офіційного перекладу якого 3 російської мови на 
українську поки що немає. Цей Закон складається з трьох глав (загальні положення; запобігання корупції, корупційні правопорушення та відповідальність за них; усунення наслідків корупційних правопорушень), що містять 17 статей. Свого часу, зважаючи на положення його мети (ст. 2), він став одним із базових нормативних орієнтирів для пострадянських держав при вдосконаленні їх національних антикорупційних законодавств.

Питання кримінальної відповідальності за ККП у цьому Модельному законі висвітлені у положеннях:

а) ст. 2 «Основні поняття», де дається визначення сімом ключовим термінам - «корупція (корупційні правопорушення)», «корупційні правопорушення, пов'язані з кримінально караними діяннями», «державні посадові особи», «державна посада», «державний орган», «державні посади державної влади (відповідальні державні посади)», «державні посади державної служби»;

б) ст. 3 «Суб'єкти корупційних правопорушень, пов'язаних з корупцією», в якій передбачається, що на підставі цього Модельного закону несуть відповідальність державні посадові особи, судді, а також прирівняні до них інші особи, зазначені у цій статті;

в) ст. 4 «Сфера застосування Закону», де, з-поміж іншого, вказано, що відповідальність за корупційні правопорушення, пов'язані 3 кримінально караним діянням, установлюється кримінальним кодексом держави;

г) ст. 12 «Правопорушення, що створюють умови для корупції, та відповідальність за них», де в межах чотирнадцяти пунктів ч. 1 цієї статті зазначено про досить специфічні види таких правопорушень, починаючи від неправомірного втручання в діяльність інших державних органів, організацій, продовжуючи протекціонізмом (сімейністю) та завершуючи участю в азартних іграх грошового або іншого майнового характеру з особами, які вищі чи нижчі за посадою або перебувають 3 ними в іншій залежності по службі або роботі (зважаючи на положення КК України всі иі правопорушення важко визнати кримінально караними та корупційними. - А. Б.);

г) ст. 13 «Корупційні правопорушення, пов'язані з протиправним отриманням благ і переваг», де фактично йдеться про різноманітні форми прояву хабарництва (підкупу), предметом яких можуть виступати винагороди у вигляді грошей, послуг та в інших формах, подарунки, запрошення, переваги тощо;

д) ст. 16 «Стягнення незаконно отриманого майна або вартості незаконно наданих послуг», де зазначається, що незаконно отримане майно та незаконно одержані послуги в результаті корупційних правопорушень підлягає зверненню (стягненню) в дохід держави.

Питання запобігання ККП містяться в положеннях про: основні принципи боротьби 3 корупцією (ст. 5); органи, що здійснюють боротьбу з корупцією (ст. 6); гарантії державного захисту осіб, які надають сприяння в боротьбі з корупцією (ст. 7); спеціальну вимогу до осіб, які претендують на виконання державних функцій (ст. 8); заходи фінансового контролю (ст. 9); діяльність, несумісна з заняттям державної посади (ст. 10); неприпустимість спільної служби близьких родичів або 
свояків (ст. 11); визнання угод недійсними та анулювання актів i дій, скоєних у результаті корупційних правопорушень (ст. 17) [6].

На наш погляд, аналізований Модельний закон є одним із небагатьох міжнародних документів на пострадянському просторі, який влучно передбачив перспективу вживання у своєму тексті єдиного терміна «корупційне правопорушення» замість «корупційний злочин», хоча i в цьому випадку очевидна певна нормативна непослідовність (наприклад, у ст. 3 відбувається повне ототожнення термінів «корупційні правопорушення, пов'язані 3 корупцією» та «корупційні правопорушення»).

Щодо Конвенції ООН проти транснаціональної організованої злочинності від 15 листопада 2000 р. (ратифбікована Україною із застереженнями $і$ заявами 04 лютого 2004 р.), то вона $\epsilon$ багатоплановою та універсальною з приводу регулювання боротьби з транснаціональною організованою злочинністю; у ній пропонуються заходи проти корупції та зазначається про відповідальність юридичних осіб щодо їх участі в серйозних злочинах, до яких причетна організована злочинність (ст. ст. 8-9). Так, у ст. 8 «Криміналізація корупції» передбачено визнати кримінально караними такі діяння, коли вони вчиняються навмисно: а) обіцянка, пропозиція або надання публічній посадовій особі, особисто або через посередників, будь-якої неправомірної переваги для самої посадової особи або іншої фізичної чи юридичної особи для того, щоб ця посадова особа вчинила будь-яку дію або бездіяльність при виконанні своїх службових

(C) Боровик А. В., 2019 обов'язків; b) вимагання або прийняття публічною посадовою особою, особисто або через посередників, будь-якої неправомірної переваги для самої посадової особи або іншої фізичної або юридичної особи для того, щоб ця посадова особа вчинила будь-яку дію чи бездіяльність при виконанні своїх службових обов'язків.

Підкреслимо, що англійський термін «solicitation» у цій Конвенції відповідає терміну «вимагання» в офіційному її перекладі українською мовою, однак переконані, що у даному випадку вживання терміна «вимагання» $\epsilon$ неточним, недоцільним і неправильним, оскільки йдеться не про агресивну форму пред'явлення вимоги (англ. - «extortion»), а про «прохання» (у т.ч. настирливе), «клопотання», «звернення». 3 цього випливає, що вказаний міжнародний документ (як і Конвенція ООН проти корупції від 31 жовтня 2003 р. у ч. 2 ст. 16) безпосередньо не потребує здійснювати криміналізацію саме «вимагання» неправомірної переваги (вигоди) з огляду на той зміст, який відбиває значення цього терміна його форма серед злочинів проти власності у розумінні українського законодавця.

Поряд із тим зазначена Конвенція встановлює, що кожна держава-учасниця повинна розглянути можливість щодо визнання кримінально караними: 1) участь у зазначених вище кримінально-караних діяннях будь-якої іноземної публічної посадової особи або міжнародного цивільного службовця; 2) інші форми корупції; 3) участь в якості спільника у вчиненні будь-якого злочину, визнаного таким відповідно до цієї статті. 
Про заходи протидії корупції говорить ст.9 цієї Конвенції, відповідно до якої кожна державаучасниця тією мірою, якою це потрібно і відповідає іï правовій системі, вживає: 1) законодавчі, адміністративні або інші ефективні заходи для сприяння добросовісності, а також для попередження й виявлення корупції серед публічних посадових осіб і покарання за неї; 2) заходи для забезпечення ефективних дій її органів у сфері попередження і виявлення корупції серед публічних посадових осіб і покарання за неї. 3 приводу відповідальності юридичних осіб (ст. 10), то зазначена Конвенція прописує, що кожна держава-учасниця має вжити таких заходів, які, з урахуванням ії правових принципів, можуть знадобитися для встановлення відповідальності юридичних осіб за участь у серйозних злочинах, до яких причетна організована злочинна група, у т.ч. й за злочини, визнані такими відповідно до ст. 8 цієї Конвенції [7].

Щодо Конвенції Африканського союзу про недопущення корупції та боротьбу з нею від 12 липня 2003 р. Manymy (Мозамбік), то, зважаючи на Преамбулу Конвенції ООН проти корупції від 31 жовтня 2003 р., ця Конвенція Африканського союзу (далі - AC) $є$ «багатостороннім документом щодо запобігання корупції та боротьби з нею», однак в нашій державі відсутній іï офіційний чи неофіційний переклад українською мовою, а вітчизняні науковці не проводили ії навіть базових досліджень. Відомо про те, що вона має статус регіональної (набула чинності 05 серпня 2006 р., iї підписали 49 із 55 африканських держав, а ратифікували лише 43) і складається з преам- були та 28 статей. I якщо положення, що стосуються кримінальної відповідальності за ККП, були певною мірою розглянуті окремими вітчизняними дослідниками (зокрема, А. В. Савченком) [8], то ті, що стосуються запобігання ККП, взагалі майже не обговорювалися. Щодо останніх, то вони представлені вузько, однак у цьому аспекті вказаний міжнародний документ говорить про: важливість доступу держав-учасниць до інформації (ст. 9); провідну роль громадянського суспільства та засоби масової інформації (ст. 12); співпрацю та взаємну правову допомогу (ст. 18); міжнародне співробітництво (ст. 19); діяльність національних органів влади (ст.20); слідування механізму реалізації положень цієї Конвенції (ст. 22). Варто наголосити, що відповідно до ст. 21 «Зв'язок з іншими Угодами» цієї Конвенції положення останньої замінюють будь-який iнший договір або двосторонню угоду, що визначає корупцію та пов'язані 3 нею правопорушення між будь-якими двома або більше державамиучасницями (тобто фактично вказана норма встановлює виключний пріоритет положень Конвенції АС над іншими антикорупційними конвенціями) [9].

Принципово важливим антикорупційним документом планетарного масштабу $є$ Конвенція ООН проти корупції від 31 жовтня 2003 р., яка, по-перше, заклала підвалини універсальної системи протидії та запобігання ККП; подруге, вважається найбільш широкою за сферою дії серед усіх міжнародних антикорупційних інструментів. 09 грудня 2003 р. вона була відкрита для підписання на Політичній конференції високого 
рівня в Меріді (Мексика), а день початку роботи конференції був оголошений Міжнародним днем боротьби 3 корупцією. На даний момент до цієї Конвенції приєдналися 172 держави. Конвенція складається з 8 глав, що об'єднують 71 статтю.

Щодо кримінальної відповідальності за ККП принципово важливими є такі положення:

а) ст. 2 цієї Конвенції, де дається визначення дев'ятьом термінам, зокрема: «державна посадова особа»; «іноземна державна посадова особа»; «посадова особа міжнародної організації»; «майно»; «доходи від злочину»; «призупинення операцій (заморожування)», або «арешт»; «конфіскація»; «предикатний злочин»; «контрольована поставка» (при цьому ключовий термін «корупція» не визначений);

б) глави III «Криміналізація та правоохоронна діяльність» (ст. ст. 1542) цієї Конвенції, згідно з якими кожна держава-учасниця має вжити такі законодавчі та інші заходи, що можуть бути необхідними для визнання кримінально караними наступних діянь: підкуп національних державних посадових осіб (ст. 15); підкуп іноземних державних посадових осіб і посадових осіб міжурядових організацій (ст. 16); розкрадання, неправомірне привласнення або інше нецільове використання майна державною посадовою особою (ст. 17); зловживання впливом (ст. 18); зловживання службовим становищем (ст. 19); незаконне збагачення (ст. 20); підкуп у приватному секторі (ст. 21); розкрадання майна в приватному секторі (ст. 22); відмивання доходів, здобутих злочинним шляхом (ст. 23); приховування (ст. 24); перешкоджання здійсненню правосуддя (ст. 25); участі та замаху (ст. 27), що охоплюють: участь в якості спільника, «підсобника» або підбурювача (ч. 1); замax (ч. 2) та приготування (ч. 3) на вчинення будь-якого злочину, що визнано таким цією Конвенцією.

У більшості випадків спеціально наголошується, що такі діяння повинні бути вчинені умисно. Крім цього, вимагається обов'язкове здійснення криміналізації діянь, передбачених ст. 15 ; ч. 1 ст. 16 ; ст. ст. 17 , $20,23,25$; ч. 1 ст. 27 , тоді як на розсуд держав-учасниць залишаються питання криміналізації діянь, про які йдеться у ч. 2 ст. 16; ст. ст. 18, 19, 21 , 22, 24; ч. 2 і 3 ст. 27 цієї Конвенції. Також у межах цієї глави передбачається вжиття заходів щодо встановлення відповідальності юридичних осіб за вчинення ними кримінально-караних діянь (ст. 26);

в) глави IV «Міжнародне співробітництво» (ст. ст. 43-50) цієї Конвенції, де закріплюються питання щодо видачі злочинців (їх екстрадиції), взаємної правової допомоги та взаємодії щодо розслідування корупційних діянь;

Питання запобігання ККП відображені в положеннях:

а) глави II «Заходи щодо запобігання корупції» (ст. ст. 5-14) цієї Конвенції, де насамперед зосереджується увага на політиці й практиці запобігання та протидії корупції (ст. 5), а також необхідності визначення органу або органів із запобігання та протидії корупції (ст. 6);

б) глави V «Заходи щодо повернення активів» (ст. ст. 51-59) цієї Конвенції, які вважаються першим міжнародним договором у сфері боротьби з корупцією, де врегульовані питання повернення активів (фак- 
тично йдеться про додаткові заходи, які були прописані у главах II i IV);

в) глави VI «Технічна допомога й обмін інформацією» (ст. ст. 60-62) цієї Конвенції, що охоплюють підготовку кадрів, збирання та аналіз інформації про корупцію й обмін такою інформацією, вжиття інших заходів здійснення аналізованого міжнародного документа, у т.ч. шляхом економічного розвитку і технічної допомоги [10]. Зауважимо, що порівняно 3 іншими міжнародними антикорупційними документами, де передбачені механізми контролю за додержанням і реалізацією їх положень, Конвенція ООН проти корупції зазначених вимог не містить.

3 приводу Конвенції Ліги арабських держав про боротьбу 3 корупцією від 21 грудня 2010 р. (Kaїр, Єzunem), то загалом вона має статус регіональної та $\epsilon$ першим офіційним загальноарабським інструментом протидії й запобігання корупції. На сьогоднішній день їі підписав 21 (із 22) член Ліги арабських держав (усі, за винятком Сомалі), тоді як ратифікувало лише понад 12 країн-учасниць. Зауважимо, що в Україні немає ані офіційного (неофіційного також) перекладу цієї Конвенції державною мовою, ані яких-небудь наукових досліджень ії положень, за винятком хіба що розробки А. В. Савченка, де висвітлено окремі кримінально-правові питання [11]. Щодо положень про запобігання ККП, то вони охоплюють: а) питання поводження 3 жертвами ККП (ст. ст. 8-15); б) заходи запобігання та контролю (ст. 10); в) заохочення організації громадянського суспільства до ефективної участі у запобіганні та боротьби 3 корупцією (ст. 11); сприяння співробітництву у правоохоронній сфері (ст. 16), між правоохоронними органами (ст. 17), органами влади (ст. 18), представниками приватного сектору (ст. 19); забезпечення взаємної правової допомоги (ст. 20) та конфіскації майна (ст. 21); передбачення механізмів навчання та технічної допомоги (ст. 31), а також збору, обміну та аналізу інформації й даних щодо корупції (ст. 32) тощо [12].

Висновки. Підсумовуючи результати дослідження окремих міжнародно-правових документів антикорупційного спрямування, слід зробити такі висновки:

1. Нині існує ціла система міжнародних документів, що регулюють питання міжнародного співробітництва різних держав світу в сфері кримінальної відповідальності та запобігання ККП. Основні 3 них були ухвалені у період з 1975 по 2010 рр., однак лише окремі з таких документів були ратифіковані Україною (зокрема, Конвенція ООН проти транснаціональної організованої злочинності, прийнята резолюцією 55/25 Генеральної Асамблеї від 15 листопада 2000 р.; Кримінальна конвенція Р€ про боротьбу з корупцією (ЕTS 173) від 27 січня 1999 р.; Цивільна конвенція Р€ про боротьбу з корупцією (ETS 174) від 04 листопада 1999 р.; Конвенція ООН проти корупції від 31 жовтня 2003 р.; Додатковий протокол до Кримінальної конвенції Р€ про боротьбу з корупцією (ЕTS 191) від 15 травня 2003 p.).

2. В одних міжнародних антикорупційних конвенціях поняття «корупція» та «хабарництво» розмежовуються між собою, а в інших вказано, що такі форми можуть бути рівнозначними проявами корупцій- 
них діянь чи актів корупції. У певних конвенціях питання кримінальної відповідальності за ККП врегульовані ширше, ніж питання щодо їх запобігання, в інших, навпаки, вузько. Попри спрямованість вказаних міжнародно-правових документів на уніфікацію антикорупційного законодавства та вироблення відповідних заходів запобігання ККП, все ж таки складно або фактично неможливо встановити єдине для всіх держав та міжнародних спільнот визначення ККП та їх переліку. Проблемною $є$ неточна, непослідовна й рудиментарна термінологія, яка використана у низці конвенцій, а також неналежний їх переклад українською мовою, що створює складнощі розуміння та застосування.
3. Щодо запобігання ККП проблемним у міжнародно-правових документах є: існування можливості внесення застережень; відсутність механізмів ефективного моніторингу реалізації конвенційних положень та контролю за дотриманням їх вимог; зосередження уваги переважно на запобіганні підкупу та хабарництва замість інших корупційних проявів; вузькість кола учасників конвенцій, до якого варто вносити не тільки держави, а й міжнародні організації. Немаловажним для держав-учасниць відповідних антикорупційних конвенцій також $\epsilon$ своєчасна ратифікація останніх та уникнення відповідних політичних переслідувань опозиції під виглядом запобігання й протидії ККП.

\section{Список використаних джерел}

1. Резолюция Генеральной Ассамблеи ООН № 3514(XXX) «Меры против коррупции, практикуемой транснациональными и другими корпорациями, их посредниками и другими причастными к этому сторонами» от 11 декабря 1975 года / Генеральная Ассамблея - Тридцатая сессия. URL: https://undocs.org/ru/ A/RES/3514\%28XXX\%29 (дата звернення: 26.11.2019).

2. Костенко Б. О., Хотієва Л. М., Вакудік М. І. Національна антикорупційна стратегія та її інституційне забезпечення : навч.-метод. матеріали. Київ : НАДУ, 2013. $68 \mathrm{c}$.

3. Соснін О. Про необхідність використання світового досвіду у боротьбі з корупцією у вітчизняній практиці. Віче. 2014. № 1-2. С. 16-18.

4. Міжамериканська конвенція проти корупції, що прийнята на третій пленарній сесії держав-членів Організації американських держав від 29 березня 1996 року. URL: https://zakon.rada.gov.ua/laws/show/998_089 (дата звернення: 28.11.2019).

5. Декларація Організації Об’єднаних Націй про боротьбу з корупцією і хабарництвом у міжнародних комерційних операціях від 16 грудня 1996 року (укр/рос). URL: https://zakon.rada.gov.ua/laws/show/995_369 (дата звернення: 28.11.2019).

6. о борьбе с коррупцией : модельный закон (принят на тринадцатом пленарном заседании Межпарламентской Ассамблеи государств - участников СНГ (постановление № 13-4 от 3 апреля 1999 года). М., 1999. 22 с.

7. Конвенція Організації Об'єднаних Націй проти транснаціональної організованої злочинності : прийнята резолюцією 55/25 Генеральної Асамблеї від 15 листопада 2000 року; ратифікована Україною 04 лютого 2004 року. URL: http://zakon4.rada.gov.ua/laws/show/995_789 (дата звернення: 29.11.2019).

8. Савченко А. В. Конвенція Африканського союзу про недопущення корупції та боротьбу з нею 2003 року: сутність кримінально-правових положень. Реалізація державної антикорупційної політики в міжнародному вимірі [Текст] : матеріали IV

(C) Боровик А. В., 2019 
Міжнар. наук.- практ. конф. (Київ, 12 груд. 2019 р.) : у 2 ч. / [редкол.: В. В. Чернєй, С. Д. Гусарєв, С. С. Чернявський та ін.]. Київ : Нац. акад. внутр. справ, 2019. Ч. 1. С. $192-$ 196.

9. African Union Convention on Preventing and Combating Corruption. Done at: Maputo. Date enacted: 2003-07-11. In force: 2006-08-05. URL: https://www.jus.uio.no/ english/services/library/treaties/04/4-04/combating-corruption.xml (дата звернення: 28.11.2019).

10. Конвенція Організації Об’єднаних Націй проти корупції від 31 жовтня 2003 року (укр/рос) (ратифікована Україною із заявами 18 жовтня 2006 року; набрання чинності для України: 1 січня 2010 року). URL: http://zakon4.rada.gov.ua/ laws/show/995_c16 (дата звернення: 28.11.2019).

11. Савченко А. В. Положення кримінального права в Конвенції Ліги арабських держав про боротьбу з корупцією 2010 року. Реалізація державної антикорупційної політики в міжнародному вимірі : матеріали III Міжнар. наук.- практ. конф. (Київ, 7 груд. 2018 р.) : у 2 ч. / [редкол.: В. В. Чернєй, С. Д. Гусарєв, С. С. Чернявський та ін.]. Київ : Нац. акад. внутр. справ, 2018. Ч. 1. С. 131-135.

12. Arab Anti-Corruption Convention. League of Arab States, General Secretariat, 2011. $19 \mathrm{p}$.

\section{References}

1. Kostenko, B. O., Hotiyeva, L. M., Vakudik, M. I. (2013). Nacionalna antikorupcijna strategiya ta yiyi institucijne zabezpechennya. Kiyiv [in Ukrainian].

2. Sosnin, 0. (2014). Pro neobhidnist vikoristannya svitovogo dosvidu u borotbi z korupciyeyu u vitchiznyanij praktici. Viche, 1-2, 16-18 [in Ukrainian].

3. Savchenko, A. V. (2019). Konvenciya Afrikanskogo soyuzu pro nedopushennya korupciyi ta borotbu z neyu 2003 roku: sutnist kriminalno-pravovih polozhen. Realizaciya derzhavnoyi antikorupcijnoyi politiki v mizhnarodnomu vimiri : materiali IV Mizhnar. nauk.prakt. konf. (Kiyiv, 12 grud. 2019 r.) : u 2 ch. / [redkol.: V. V. Chernyej, S. D. Gusaryev, S. S. Chernyavskij ta in.]. Kiyiv: Nac. akad. vnutr. sprav, 1, 192-196 [in Ukrainian].

4. Savchenko, A. V. (2018). Polozhennya kriminalnogo prava v Konvenciyi Ligi arabskih derzhav pro borotbu z korupciyeyu 2010 roku. Realizaciya derzhavnoyi antikorupcijnoyi politiki v mizhnarodnomu vimiri : materiali III Mizhnar. nauk.- prakt. konf. (Kiyiv, 7 grud. 2018 r.) : u 2 ch. / [redkol.: V. V. Chernyej, S. D. Gusaryev, S. S. Chernyavskij ta in.]. Kiyiv: Nac. akad. vnutr. sprav, 1, 131-135 [in Ukrainian].

A. Borovyk, PhD in Law, Associate Professor, Professor at the Department of Criminal Law and Justice of International University of Economics and Humanities named after academician Stepan Demianchuk

e-mail: aborovychok@gmail.com; ORCID: 0000-0003-1834-404X

\section{Question of criminal liability and prevention of corruption criminal offenses in provisions of separate international documents}

The article deals with the issues of criminal responsibility and prevention of corruption criminal offenses in the provisions of separate international documents - conventions, resolutions, declarations, model codes and so on. It is established that the main international documents, regulating the issues of international cooperation of different countries of the world in the field of criminal responsibility and 
prevention of corruption criminal offenses, were approved between 1975 and 2010 , but only some of them were ratified by Ukraine.

Considering the importance, adherence to principles, practical significance or unexploredness of certain international anti-corruption instruments for criminal law and criminology in a comparative legal context, the following scientific studies were elaborated: the Inter-American Convention against Corruption 1996 (Aadopted at the third plenary session of the Organization of American States); the United Nations Declaration against Corruption and Bribery in International Commercial Transactions (1996); the Model Law on Combating Corruption (Adopted at the 13th plenary session of the CIS Inter-Parliamentary Assembly of States, 1999); the United Nations Convention against Transnational Organized Crime (2000); the African Union Convention on Preventing and Combating Corruption (2003); The United Nations Convention against Corruption (2003); the Arab Anti-Corruption Convention (2010).

It is established that in some international anti-corruption conventions the concepts of «corruption» and «bribery» are distinguished from each other, and in others it may be stated that such forms tantamount to deeds of corruption or acts of corruption; in certain conventions, the issue of criminal responsibility for corruption criminal offenses is regulated more broadly than the issue of preventing it, while in others it is narrow; in practice, it is difficult or virtually impossible to establish, for all states and international communities, the definition of corruption criminal offenses and their list; problematic is the inaccurate, inconsistent and rudimentary terminology used in a number of conventions, as well as their incorrect translation into Ukrainian.

Concerning the prevention of corruption criminal offenses, the problem in international legal documents is: the existence of the possibility of making reservations; lack of mechanisms to effectively monitor the implementation of convention provisions and control compliance with their requirements; focusing primarily on the prevention of graft and bribery instead of other corrupt practices; the narrowness of the circle of parties to the conventions, to which not only states, but also international organizations should contribute, and so on.

Keywords: corruption criminal offenses; corruption; bribery; convention; resolution; declaration; model code. 